\title{
İkna Teorileri Çerçevesinde Yapı Reklamlarının Analizi*
}

\author{
Ali Arıcı (Öğr. Gör.) \\ Bilecik Şeyh Edebali Üniversitesi Bozüyük Meslek Yüksekokulu \\ ali.arici@bilecik.edu.tr \\ Özgür Kılınç (Arş. Gör.) \\ İnönü Üniversitesi İletişim Fakültesi \\ ozgur.kilinc@inonu.edu.tr
}

Başvuru Tarihi: 06.05.2018

Yayına Kabul Tarihi: 20.06.2018

Yayınlanma Tarihi: 30.07.2018

\section{Öz}

Bilgi vermek, dikkat çekmek, etkilemek, tanıtmak, hatırlatmak, pazarlama iletişimi çabalarını desteklemek, ürün veya markaya değer eklemek gibi standart işlevleri olan reklam, imaj tesis ederek ürünlerin / markaların algı yönetimine katkıda bulunmaktadır. Söz konusu reklamlarda duygusal satış vaadi (ESP) diline uygun olarak inşa edilen söylem, ikna teorileri temelinde araștırılmaya değer görünmektedir. Yaratıcı stratejisi bakımından dile getirdiği savlar ve imaj söylemiyle dikkat çeken yapı reklamları "Ethos-Pathos-Logos (Aristo)", "İhtiyaçlar Hiyerarşisi (Maslow)", "Gizli İhtiyaçlar (Packard)”, "Azlık Prensibi (Cialdini)” gibi ikna literatüründe yer tutan teoriler / kavramlar çerçevesinde yorumlanabilir görünmektedir. Bu doğrultuda araştırmada -geleneksel kitle iletişim araçlarından biri olan- ulusal televizyon kanallarının prime time kuşağı temel alınmaktadır. Televizyon kanallarının prime time aralığında (20.00-00.00) ilk kuşakta gösterilen yapı reklamları araştırmanın örneklemini oluşturmaktadır. Tesadüfi örneklemle söz konusu zaman diliminde gösterilen ilk sıradaki yapı reklamları, Puto ve Wells'in mesaj stratejileri; Aristo, Packard ve Cialdini'nin iknaya yönelik ve Maslow'un ihtiyaçlara yönelik yaklaşımları temel alınarak analiz edilmektedir. Söylem olarak irrasyonel çekicilik ögeleri içeren -özellikle yüksek ilginlik isteyen ürünlerin yer aldığı- reklamlarda yaşam tarzına yönelik transformasyonel dilin kullanıldığı görülmektedir. Sınıflandırma bağlamında ürün ve hizmet reklamlarından olan yapı reklamları Puto ve Wells'in ifade ettiği "kullanıcı imajı" ve "marka imajı" gibi transformasyonel mesaj stratejisine uygun iletişim unsurları taşımaktadır.

Anahtar Kelimeler: İkna, Yapı Reklamları, Reklam ve Kültür.

\footnotetext{
* Bu çalışma 18-20 Mayıs 2017 tarihinde Alanya'da düzenlenen "Il. Uluslararası Sosyal Bilimler Sempozyumu”nda "Íkna Teorileri
} Çerçevesinde Yapı Reklamlarına Yönelik Söylem Analizi” başığıyla sunulan bildirinin genişletilmiş halidir. 
Conference Paper

\title{
Analysis of Construction Advertisements Within the Framework of Persuasion Theories
}

\author{
Ali Arıcı (Lect.) \\ Bilecik Şeyh Edebali University Bozüyük Vocational School \\ ali.arici@bilecik.edu.tr \\ Özgür Kılınç (Res. Asst.) \\ İnönü Üniversitesi Faculty of Communication \\ ozgur.kilinc@inonu.edu.tr
}

Date Received: 06.05.2018

Date Accepted: 20.06 .2018

Date Published: 30.07.2018

\begin{abstract}
Advertisements, which have standard functions such as giving information, drawing attention, influencing, promoting, reminding, supporting marketing communication efforts, adding value to a product or brand, contribute to perception management of products / brands by establishing an image. The discourse, which is constructed in accordance with the emotional sales promise (ESP) in these ads, seems to be worth investigating on the basis of persuasion theories. Construction ads that attract attention with their arguments and image discourse in terms of creative strategy seems to be interpretable within the framework of theories / concepts involved in persuasion literature such as "Ethos-Pathos-Logos (Aristo)", "Hierarchy of Needs (Maslow)", "Hidden Needs (Packard)", "The Principle of Scarcity (Cialdini)." In this direction, the research is based on the prime time period of national television channels, which is one of the mass communication tools. The construction ads shown in the first period of the prime time interval (20.00-00.00) of the five most watched channels constitute the sample of the research. With the random sampling, the first construction ads shown in that time period are analysed based on Puto and Wells' message strategies, approaches of Aristotle, Packard and Cialdini towards persuasion and Maslow's approach towards the needs. It is observed that in advertisements containing irrational appeals elements -especially those with high involvement- as discourse, transformational language is used for lifestyle. In the context of classification, construction ads that are product and service ads have communication elements appropriate to the transformational message strategy, such as "user image" and "brand image" expressed by Puto and Wells.
\end{abstract}

Keywords: Persuasion, Construction Ads, Advertising and Culture. 


\section{Giriş}

Toplumla sürekli ve yoğun bir diyalog sürdüren (Rocha, 2013,1) ve popüler kültürün bir parçası haline gelen reklam (Stavrakakis, 2000,1) modern toplumdaki en etkili sosyalleşme uygulamalarından biridir (Jhally, 1990, 1). Tüketici kültürünün önemli bir boyutu olan reklam, kendimizi ve başkalarını nasıl gördüğümüzün yani insanların kimlik ve toplum algılarının da bir ögesidir (Wharton, 2015, 1).

Jhally (1990, 1-2) insanlar ve onların nesneleri arasındaki ilişkinin, yaşamın yüzeysel veya isteğe bağlı bir özelliği olarak görülmemesi gerektiğini bu durumun insan varoluşunun tanımsal bir bileșeni olduğunu; insanın kendi dışında olanı sürekli alarak bunu faaliyetleriyle gündelik varoluşunun bir parçası haline getirdiğini ve nesnelerle ilgili bir söylem olarak reklamcılığın, insanın temel yönlerinden biri ile ilgili olduğunu dile getirmektedir. Beasley ve Danesi ise $(2002,14)$ reklamcllığın 19. yüzyllın sonundan günümüze, tüketimi bir yaşam biçimi olarak teşvik etmede herhangi bir ekonomik süreçten ya da sosyal-siyasal hareketten çok daha başarılı olduğunu belirtmektedir. Diğer bir ifadeyle modern çağın en ilginç disiplinlerinden biri olan reklam, ürünlere, kurumlara, marka adlarına, yaşam tarzlarına ve kamusal konulara yönelik tutumları etkileyen bir iletişim aracıdır (Chand ve Chaudhary, 2012, 40).

Belirli görme biçimlerini teşvik eden reklamların (Collins ve Kearns, 2008, 2921) kültürel birer yapı olması bu iletişim pratiğini toplumsal ve kültürel alana yönelik birer analiz birimi haline getirmektedir. Bir toplumsal yapıdaki temsil biçimleri, dil ve tüketim kültürü reklamlar üzerinden analiz edilerek çeşitli çıkarımlarda bulunmak mümkündür.

Gerek kültür ile olan ilişkisi, gerekse bireyin ihtiyaçlar ve istekler temelinde reklam ile kurduğu ilişki ve medya ile diğer ortamların içeriklerinde yer alması reklamın gündelik hayat içerisindeki görünürlüğüne vurgu yapmaktadır. Reklam, bireyleri / alıcıları duygusal, bilişsel ve davranışsal açıdan etkilemeye çalışan bir iletişim pratiğidir. Bu iletişim pratiği farklı mesaj stratejileri / yaratıcı strajiler üzerinden yapılandırılıp sunulsa da muhtemelen reklam ile en fazla ilişkili olan kavramlardan biri iknadır. İkna edici bir iletişim faaliyeti olarak reklam, neyin, nasıl söylenmesi gerekliliği üzerinden reklamın alıcılarına yönelmektedir.

Reklam, alıcılarına birtakım ürünlere, hizmetlere veya kurumlara yönelik mesajları / anlatıları merkeze alarak ulaşmakta ve onları ikna etme amacına yönelmektedir. Bu noktada yapı reklamları birer analiz birimi işlevi görmektedir. Dolayısıyla bu çalışma, yapı reklamlarını Puto ve Wells'in mesaj stratejileri; Aristo, Packard ve Cialdini'nin iknaya ve Maslow'un ise ihtiyaçlara yönelik yaklaşımlarını temel alarak analiz etmeyi amaçlamaktadır. Çalışmada öncelikle ikna teorilerine değinilmekte; ardından yapı reklamlarına yönelik yapılmış olan araștırmalar incelenmekte; bunu ise yöntem, bulgular ve sonuç bölümü takip etmektedir.

\section{İkna Teorileri ve Reklam}

İkna, başkalarının belirgin değerlerini, isteklerini, inançlarını ve eylemlerini değiştirmeye çalışan bir süreç (O’Shaughnessy ve O'Shaughnessy, 2004, 5); başkalarından gelen bilgilere maruz kalmaktan kaynaklanan tutum değişikliği (Olson ve Zanna, 1993, 135) olarak tanımlanabilir. Yani ikna, bireyin bir nesneye, kișiye, kuruma ya da olaya yönelik olumlu veya olumsuz tepkisel eğilimi olan tutumları (Ajzen, 2005, 3) etkileme amacı taşımaktadır. 
O’Keefe (1990) iknanın belirli koşulları içermesi gerektiğini belirtmektedir. Öncelikle ikna, bir hedef ve mesajın göndericisi tarafından bu hedefe ulaşma niyetini içerir. İkincisi, iletişim söz konusu hedefe ulaşmada bir araçtır. Üçüncüsü ise ikna edici mesajın alıcısı özgür iradeye sahip olmalı ve zorlanmamalıdır. Yani ikna tesadüfi ve zorlayıcı olmayıp doğal olarak iletişimseldir. Dolayısıyla iknanın amaca yönelik bir niyeti, alıcıları zorlamadan iletişim üzerinden yapılandırarak sunduğu söylenebilir.

Bir değişim yaratma amacı üzerine inșa edilen iknanın ve ikna ile ilgili sistematik düşünmenin tarihsel temelleri M.Ö. 5. yüzyıla özellikle de Aristo'ya kadar götürülebilse de 20. yüzyılın başlarında sosyal bilimsel yöntemlerin gelişmesiyle birlikte kavrama yönelik yeni yaklaşımlar ortaya çıkmış olup son 50 yıldır ise sosyal bilimsel ikna araştırmaları artış göstermiştir. İletişim, sosyoloji, psikoloji, siyaset bilimi ve antropoloji gibi neredeyse bütün sosyal bilimler alanında ve reklamcılık, pazarlama, işletme gibi sosyal bilimlerin uygulamalı alanlarında iknaya yönelik araştırmalar gerçekleştirilmektedir (O’Keefe, 2004, 34).

İknaya yönelik farklı disiplinler kapsamında gerçekleştirilen araştırmalar birtakım kuramsal yaklaşımların da yapılandırılmasına zemin hazırlamıştır. Borchers (2013, 35) ikna kuramlarını, iknanın kaynak, hedef kitle, mesaj ve araç olmak üzere farklı bileșenlerinden hareketle Tablo 1'deki gibi sınıflandırmaktadır.

Tablo 1: İkna Kuramları

\begin{tabular}{|l|l|}
\hline Kuram & Odak \\
\hline 1. Aristo'nun İkna Kuramı & Mesajın üretimi ve kaynak \\
\hline 2. İknanın Beş Prensibi & Mesajın üretimi ve sunum \\
\hline 3. Göstergebilim & Anlam \\
\hline 4. Bilişsel Uyumsuzluk Kuramı & Hedef kitlenin alımlaması ve süreç \\
\hline 5. Problematik Bütünlük Kuramı & Hedef kitlenin alımlaması ve süreç \\
\hline 6. Ayrıntılandırma Olasıı̆ı Modeli (ELM) & Hedef kitlenin alımlaması ve süreç \\
\hline 7. Sembolik Yakınsama Kuramı & Sosyal etkileşim ve anlam \\
\hline 8. Kullanımlar ve Doyumlar & Medyanın kullanımı \\
\hline 9. Ekme Analizi & Medya etkileri \\
\hline 10. Gündem Belirleme & Medya etkileri \\
\hline Kaynak: Borchers, 2013, 35. & \multicolumn{2}{|l}{} \\
\hline
\end{tabular}

Tablo 1'de yer alan ikna kuramları değerlendirildiğinde ilk iki kuramın mesajın kendisine, kaynağına ve sunumuna odaklandığı; genel olarak gösteren, gösterge ve gösterilen çerçevesinde anlamın düz ve yan anlam olarak nasıl somutlaştığına yönelen göstergebilimin anlama odaklandığı; dördüncü, beşinci ve altıncı kuramların ise hedef kitlenin mesajı alımlama sürecine odaklandığı görülmektedir. Sembolik yakınsama kuramının sosyal etkileşim ve anlam aracılığıyla iknayı ele aldığı; son olarak da iknaya yönelik medya etkileri merkezli üç kuramın iknayı kitle iletişim araçları bağlamında yorumladıklar belirtilebilir. İkna kuramları çeşitli araştırmacılar tarafından sınıflandırılmış olsa da bu çalışmada sadece Aristo, Packard ve Cialdini'nin iknaya yönelik yaklaşımlarına yer verilmiştir.

Aristo ikna eyleminde artistik olan ve olmayan kanitlardan bahsetmektedir. Artistik olmayan kanıtlar çevre tarafından kontrol edilirken; artistik kanıtlar ise iknacıya ait olan özellikler olup ethos, pathos ve logos olmak üzere üçe ayrılmaktadır. Ethos güven; pathos duygu; logos ise bilgi ile ilişkilidir (Borchers, 2013, 39-40; Steinberg, 2006, 14-15). Diğer bir ifadeyle ethos, hedef kitleyi iknacının güvenilirliği 
ya da karakteri ile ikna etmeyi amaçlayan etik bir çekilik; pathos, öfke, korku ya da sempati yaratarak hedef kitleyi ikna etmeyi amaçlayan duygusal bir çekicilik; logos ise hedef kitleyi mantık ya da akıl kullanımıyla ikna etmeyi amaçlayan bilgisel bir çekiciliktir (Green, 2004).

Higgins ve Walker $(2012,198)$ ethos, pathos ve logosu kapsayan retoriksel çekicilik unsurlarını Tablo 2'deki gibi kavramsallaştırmaktadır.

Tablo 2: Retoriksel Çekicilik Unsurları

\begin{tabular}{|l|l|}
\hline Çekicilik & İkna tekniği örnekleri \\
\hline \multirow{5}{*}{ Ethos: Güven } & Benzerlik \\
& Kendini kabul ettirme \\
& Saygı \\
& Uzmanlık \\
& Öz eleştiri \\
& Başarı eğilimi \\
& Tutarlıık \\
\hline & Metaforlar \\
& Betimleme (özellikle aşağıdaki kültürel referanslar aracıllığıyla): \\
& Mizah \\
& İman azlığı \\
& Sağlık ve refah \\
& Umut ve tutku \\
& Sadakat \\
& Arkadaşlık \\
& Sempati \\
\hline Pathos: Duygu & Kanıtlama \\
& Mantık \\
& Nedenler / gerekçeler \\
& İddialar \\
\hline Logos: Bilgi & Veri \\
& Kanıtlar / örnekler \\
\hline
\end{tabular}

Tablodaki retoriksel çekicilik unsurlarına bakıldığında kaynağın güven, duygu ve bilgi özelliklerinin ön plana çıktığı görülmektedir. Bahsi geçen özelliklerin reklam bağlamında "transformasyonel ve bilgilendirici" gibi reklam mesajlarında somutlaştığını dile getirmek yanlış olmayacaktır. Yine ethos kapsamındaki ikna tekniklerinin reklamda tanık / ünlü kullanımı stratejisi ile ilişkili olduğu belirtilebilir. Bu noktada Puto ve Wells'in (1984) "bilgisel" ve "transformasyonel" olmak üzere ikiye ayırdığı reklam mesaj stratejilerine değinmek yerinde olacakır.

Puto ve Wells'in $(1984,638)$ "bilgisel" ve "transformasyonel" olmak üzere ikiye ayırdığı reklam mesaj stratejileri kapsamında bir reklamın bilgisel olarak adlandırılabilmesi için;

- Marka ile ilgili olgusal bilgiler sunması,

- Potansiyel tüketiciler için doğrudan doğruya önemli olan bilgiler sunması ve

- Tüketicinin, doğrulanabilir olduğunu kabul ettiği veriler sunması gerekmektedir

- Transformasyonel reklamlar ise (Puto ve Wells, 1984, 638);

- Ürün, reklamı yapılan markanın sadece objektif bir tanımından ziyade daha zengin, daha sıcak, daha heyecan verici ve daha keyifli bir kullanım deneyimi sağlamalıdır.

- Reklam deneyimini - tüketicilerin, reklamın yarattığı deneyimi hatırlayamadan markayı hatırlayamadığı - marka kullanım deneyimiyle çok sıkı bir şekilde ilişkilendirmelidir. 
İkna kuramları kapsamında değinilecek ikinci yaklaşım ise Packard'ın (1964) dile getirdiği sekiz gizli ihtiyaçtır. Söz konusu ihtiyaçlar "duygusal güven, değer tatmini, ego tatmini, yaratıcılık, sevme ve sevilme, güç duygusu, kökler ve ölümsüzlük”tür.

Duygusal güvenlik, çocukların duygularının, davranışlarının, düşüncelerinin ve fizyolojik tepkilerinin genel olarak örgütlenmesinden ve anlamlarından çıkarılabilen örtük bir yapı olup, çocukların sosyal bağlamlarda kendi işleyiş̧ini düzenleyen, böylece sosyal, duygusal, bilişsel ve fizyolojik tepkileri yönlendiren bir amaçlar dizisi olarak işlev görmektedir (Davies ve Cummings, 1994, 388).

Ego tatmini, takdir edilme duygusu olup (Sieber, 1974'ten aktaran Thoits, 1983, 175); değer tatmini bir kişinin yetkinliğinin, becerilerinin ve değerinin başkaları tarafından tanınmasıdır (Cutrona ve Russel, 1987, 39). Yaratıcılık ise hem özgün (orijinal, beklenmeyen) hem de uygun (yararlı) işler üretme yeteneğidir (Sternberg ve Lubart, 1999, 3).

Sevmek, sevgi nesnesine karşı güçlü sevgi ve şefkat hisleri içeren karmaşık bir duygudur. Her ne kadar sevgi, insan sevgisi, aile sevgisi, cinsel sevgi ve öz sevgi gibi birçok şekil alsa da Üçgen Aşk kuramı "tutku, mahremiyet ve bağlılık" olmak üzere üç temel bileşen önermektedir (https://dictionary.apa.org/love). Güç duygusu, kişinin başka bir kişiyi veya başka insanları etkileme yeteneği algısı olup, gücün, başkalarını etkileme kapasitesi olarak tanımlandığını da belirtmek önem taşımaktadır (Anderson ve diğerleri, 2012, 316). Kökler, belirli bir yere ait olma ihtiyacına dayanmakta (Moring, 2000, 174; ölümsüzlük ise ölüm ile karşı karşıya kalmamaktır (Horrobin, 2006, 287).

Sekiz ihtiyacın daha çok bireyin psiko-sosyal ihtiyaçları ile ilişkili olduğu görülmektedir. Reklamların, tüketicilerin sadece fiziksel ihtiyaçlarına değil de aynı zamanda statüye, prestije ve ürünler aracılığıyla kimlik inșasına yönelik söylemleri düşünüldüğünde bahsi geçen sekiz ihtiyacın reklam anlatılarında nasıl kullanıldığı görünür bir nitelik kazanmaktadır. Öyle ki pazar ve kültürel anlamlar arasında dinamik bir ilişkinin olduğu (Tiwsakul ve Hackley, 2012, 491); markaların benlik inşasında kullanıldığı (Schembri ve diğerleri, 2010, 635); gönüllü olarak yapılan tüm tüketim eylemlerinin farkında olunarak veya olunmayarak sembolik anlamlar taşıdığı (Elliot ve Wattanasuwan, 1998, 134) ve tüketicilerin, ürün seçiminde markaların sembolik imgelerini kendi benlikleriyle eşleştirmeye çalıştıkları (Mittal, $2015,98)$ söylenebilir. Reklamlar da bu süreçte bir aracı işlevi görmektedirler. Söz konusu aracı rolün ikna edici bir iletişim söylemi üzerinden şekillendiği söylenebilir.

Packard'ın dile getirdiği sekiz ihtiyacın bireylerin kimlikleri ile de ilişkili olduğu düşünüldüğünde toplumsal temsilin belirli bir biçimi olan kimlik, birey ve sosyal dünya arasındaki ilişkiye aracılık etmekte (Chryssochoou, 2003, 225); bireyin "kim olduğunu" belirten bir anlamlar kümesi sunmakta (Burke ve Stets, 2009, 3) ve hem kişisel hem de toplumsal boyutları içermektedir (Dittmar, 2008, 8). Bu bağlamda kimliklerimizin birer gösterenleri olarak nesneler şu üç işlevi yerine getirmektedir (Millan ve Reynolds, 2014, 552).

- Benlik algisını yaratmak ve yansıtmak

- Bireysel güç ve statünün göstergesi olmak

- Sosyal entegrasyon ve bireysel farklılığı temsil etmek 
Nesneler ve gizli ihtiyaçlar arasındaki sembolik ilişkinin bireylerin psiko-sosyal ihtiyaçlarının yanı sıra fiziksel ihtiyaçları ile de ilişkili olduğunu belirtmek gerekmekte; bu noktada psiko-sosyal ihtiyaçların yanı sıra fiziksel ihtiyaçlara da değinen Maslow'un yaklaşımını değerlendirme gerekliliği ortaya çlkmaktadır. Maslow (1954) önemli öncelikler içeren beş farklı ihtiyacın olduğunu belirtmektedir. Birinci seviye "fizyolojik ihtiyaçlar" olup bu seviyede bireyin başka bir şey düşünmeden önce yiyecek, su ve uyku gibi ihtiyaçlarını gidermesi üzerinde durulmaktadır. İkinci seviye, iş ve sağlık ile fiziksel ve duygusal durumlarla ilişkili olan "güvenlik"tir. Üçüncü seviye, "aidiyet ihtiyacıdır" ve bu ihtiyaç, yüzeysel ya da anlamlı ilişkiler ile karşılanabilir. Bunu "değer ihtiyacı" izlemekte, bu ihtiyaç bir gruba veya ilişkiye ait olma ile ortaya çıkmaktadır. Son seviye ise "kendini gerçekleştirme" ihtiyacıdır. Maslow'a göre (2010) kendini gerçekleștirme, bir insanın tatmin etmeyi amaçladığı nihai ihtiyaçtır.

Maslow'un yaklaşımında fiziksel ihtiyaçların tatmininden başlayarak; psiko-sosyal ihtiyaçların tatminine yönelen hiyerarşik bir yapının olduğu görülmektedir. Diğer bir deyişle bireyler öncelikle temel fiziksel ihtiyaçlarını; ardından güvenlik, ait olma ve değer görme ihtiyaçlarını karşılama eğilimi içerisindedirler. Ürün ve hizmetlerin sunduğu sembolik değerlere sahip olmanın, nesnelerin benlik algısını yarattığı ve yansıttığı görüşünden hareketle kendini gerçekleştirme ihtiyacı ile ilişkili olduğu söylenebilir. Reklam, hedef kitlenin sosyo-psikolojik statüsünü ve ait olduğu genel kültürü yansıttığından kendine ait güçlü anlamlar dizisini iletmektedir. Günümüz dünyasında reklamcılık, bir pazarlama iletişimi aracı olmanın yanı sıra bir değişim nesnesidir. Yani tüketiciler, prestij markalara sembolik değerleri için daha fazla ödeme yapmaya istekli oldukları sürece reklam bir değişim aracı olma rolünü sürdürecektir (Lee, 2010, 45).

Maslow'un hiyerarşik yaklaşımı "reklam nasıl çalışır?" sorusuna verilen hiyerarşi merkezli yaklaşımları çağrıştırmaktadır. Özellikle ihtiyaçlar - dikkat - ilgi - arzu eylem - tatmin hiyerarşik sıralamasını izleyen AIDA / NAIDAS modelleri Maslow'un yaklaşımıçerçevesindeyorumlanabilir.Yani,reklamınönceliklebirihtiyacaseslenmesi - Maslow'un fiziksel ya da psiko-sosyal ihtiyaçlara yönelik kavramsallaştırması- ve bu doğrultuda dikkat çekmesi, ilgi ve arzu uyandırması, alıcıları eyleme yöneltmesi ve onlarda tatmin duygusunu sağlaması şeklinde sıralanan hiyerarşik söylem, reklamı belirli bir işleyiş sıralaması içerisine konumlandırmaktadır. Öte yandan reklamda hiyerarşi temelli modellerin eleștirildiği, bir değişken olarak "ilginliğin" de (ikna kuramları bağlamında ELM ile ilişkili olarak) reklamın işleyiş sürecinde etkili olduğunu belirtmek gerekmektedir.

Son olarak Cialdini'nin insan davranışlarının altı temel eğilimine değinmek yerinde olacaktır. Cialdini $(2001,76)$ insan davranışının altı temel eğiliminin olumlu bir tepki üretmede devreye girdiğini; söz konusu eğilimlerin "karşılıklılık, tutarlılık, sosyal geçerlilik, beğenme, otorite ve azlık" olduğunu belirtmektedir. Bu altı eğilim, iş ilişkilerini, sosyal ilginlikleri ve kişisel ilişkileri yönetmeye yardımcı olmaktadır. Algılanan azlığın bireylerin kararları üzerinde etkisi bulunmaktadır. Nesneler ve firsatlar daha az erişilebilir hale geldikçe bireyler için daha çekici bir nitelik kazanmaktadır. Dolayısıyla pazarlamacılar, "sınırlı süreli" promosyonları ya da "sınırlı üretim" temelindeki satış kampanyalarını kullanarak birbirleriyle rekabete girmektedirler (Cialdini, 2001, 76-80). 
Karşılıklılık, bir kimsenin bir diğerinden fayda sağladığı ve karşılığında eş değer bir fayda sunduğu bir eylem, süreç veya ilişki durumudur (https://dictionary.apa.org/ reciprocity). Tutarlılık, davranışın tutarlı olması iken (https://en.oxforddictionaries. com/definition/consistency); sosyal geçerlilik, bir davranışın odağını, sürecini ve etkilerini değerlendirmede sosyal kriterlerin göz önünde bulundurulmasıdır (Kazdin 1982'den aktaran Page ve Thelwell, 2013, 62). Beğenme, sevgi ya da şefkat olarak görülebilen ve bir başkası için hissedilen duygusal bir bağlantıdır (Nicholson ve diğerleri, 2001, 5). Otorite ise düşünce, fikir veya davranışı etkileme veya yönetme gücüdür (https://www.merriam-webster.com/dictionary/authority).

Yukarıda sıralanan eğilimler reklamlar açısından değerlendirildiğinde özellikle azlık prensibinin, yüksek ilginlik gerektiren seçici ürün kategorilerinde "sınırlı sayıda" söylemi üzerinden kurulduğu; reklamların kültürel bir bağlam içerisinde inşa edilmesinin de sosyal geçerlilik ile ilişkili olduğu söylenebilir. Diğer bir anlatımla reklamların kültürel yapı ile uyumlu bir görüntü sergilemesi sosyal geçerlilik eğilimini içerir bir nitelik sunmaktadır. Beğenme eğiliminin reklamlarda transformasyonel yani duygu merkezli reklam anlatısı, mesajları üzerinden aktarılması ise reklam ve beğenme eğilimi arasındaki ilişkiye vurgu yapar niteliktedir. Son tahlilde ise reklamın ikna edici yanının yani reklamda ikna anlatısının önemi ortaya çıkmaktadır.

Tüketicilerin kalplerini ve zihinlerini kazanması gereken reklamcılıkta (Verlegh ve diğerleri, 2015, 3) ikna her geçen gün daha da önemli hale gelmektedir (O'Shaughnessy ve O'Shaughnessy, 2004, 1). Diğer bir anlatımla bütün reklamlar, bilgilendirmek, hatırlatmak ve ikna etmek amacıyla tasarlanmaktadır (Ambler, 2000, 301). Bahsi geçen amaçlara ulaşmak mesajın ikna edici bir şekilde yapılandırılmasını gerektirmektedir. İknanın temel amacının bir değişim yaratma üzerine kurulu olduğu düşünülügünde reklamcılık bağlamında söz konusu değișimin en nihayetinde satın alma davranışına yol açmak olduğunu söylemek yanlış olmayacaktır.

Reklam, tüketicileri pazarlamanın sonuçlarını en üst düzeye çıkaracak şekilde ikna etmeyi amaçlayan bir kitlesel bilgi iletişimidir. Tüketiciyi bir ürünü satın almaya ikna etmek için reklamverenin ikna edici mesajlar üretmesi; bunun için de reklamverenin tüketici değeri, tutumu, sınıfı ve kültürü gibi bilgileri analiz etmesi gerekmektedir (Lee, 2010, 33). Bu noktada tüketicilerin değerleri, tutumları, kültürleri ve yaşam biçimleri ile ilişkili olan yapı reklamları karşımıza çıkmaktadır.

\section{Yapı Reklamları}

TDK Güncel Türkçe Sözlük yapı kelimesini "barınmak veya başka amaçlarla kullanılmak için yapılmış her türlü mimarlık eseri, bina” olarak tanımlamaktadır (http://www.tdk.gov.tr/). Yapı reklamları da tıpkı diğer birçok ürün ve hizmet kategorisinde olduğu gibi toplumsal alana, yaşam tarzına ve reklamın neyi, nasıl söylediğine yönelik analiz yapmayı mümkün kıldığından çeşitli araştırmalara konu olmuştur. Söz konusu araştırmaları kısaca incelemek yerinde olacaktır.

Cheung ve Ma $(2005,66)$ Hong Kong'taki yaşam tarzının nasıl değiştiğini konut reklamları üzerinden inceledikleri çalışmada özellikle konut reklamlarını seçme gerekçesi olarak çalışmanın odağında yer alan idealize edilmiş yaşam tarzlarının ve bunların sosyal anlamlarının neler olduğunu yeniden betimleme olduğunu belirtmektedir. Araştırmacılar, konut sorununun Hong Kong'un savaş sonrası sosyal gelișiminde süregelen bir konu olduğunu ve bireylerin değerlerinde, aile 
yorumlarında ve aidiyet duygularında önemli bir rol oynadığını dile getirmektedir. Bireyler bir yandan çeşitli olanakların mevcut olduğu bir yerde yaşamak istemekte; diğer yandan, sahip oldukları her şeyin gerçek olandan farklı hatta "doğa"nın sadece ekrandaki bir görüntü olduğunu hemen anlamaktadırlar (Cheung ve Ma, 2005, 77). Bu durum da gerçeğin, reklam ile olan ilişkisini vurgulayarak Pollay'in (1986) reklama yönelik dile getirdiği "çarpıtılmış ayna" metaforunu akla getirmektedir.

Yapı reklamlarına yönelik bir diğer araștırma Ramer-Biel ve First (2011) tarafından yapılmıştır. Araştırmacılar yaşlı bireylere yönelik konut reklamlarını incedikleri araştırmada şu dört boyutu vurgulamışlardır:

- Fiziksel: Konutun konumu ve sağladığı hizmetler de dahil olmak üzere konutun kendisi ile ilgili özellikler

- Sosyal: Aile üyelerinin, arkadaşların ve toplumun rolü, sunulan sosyal aktiviteler ve konutun sosyal statüye etkisi

- Kültürel: Sunulan boş zaman aktivitelerine yönelik özellikler

- Ekonomik: Fiyat ve ödeme seçeneklerinin belirtilmesi de dahil olmak üzere bir mülkiyet olarak konutun özellikleri

Araștırmanın sonuçlarından görüldüğü üzere konut reklamları fiziksel, sosyal, kültürel ve ekonomik çeşitli yapılara gönderme yapmakta; reklam mesajı, alıcılarının fiziksel ve psiko-sosyal ihtiyaçlar anlatısı üzerinden ikna içeriklerine yönelmektedir.

Collins ve Kearns'da $(2008,2915)$ gayrimenkul reklamlarının, izeyicilerin mekanı anlamalarına aracı olduğunu yani reklamın sembolik işlevi ile mülkiyetin maddi düzenlemesi arasında bir ilişki olduğunu dile getirmektedir. Mekanı anlamada reklamın sembolik işlevinin tüketicilerin kendilerini başkalarından farklılaştırma şeklinde bir işleve de sahip olduğu dile getirilebilir. Bu doğrultuda Americus ve diğerlerinin $(2009,124)$ belirttiği gibi toplumsal kimlikler, tüketicilerin kendilerini ifade etmek için kullandıkları çok çeşitli ve akışkan "etiketler" olup, tüketiciler bu etiketler aracılığıyla kendi kimliklerini ifade etmekte ve yine kendilerini diğerlerinden farklılaştırmaktadırlar.

Piyasalar aracılığıyla konut tedarikinin bir parçası olarak işlev gören reklam, konutun fiziksel özelliklerini iletmenin bir yoludur. Satış reklamcılığı, konut birimlerinin prototipik tasarımları yerine iç mekânsal düzen ve niteliksel eklemelerle ilgili yeni özelliklerine odaklanmaktadır. Bu süreç, konut sektöründeki rekabeti artırmakta ve yatırımcılar, tüketicilerin, konutun zemin alanına, konumuna, manzarasına, sosyal yapısına, etkileşimine, mahremiyetine ve diğer özelliklerine ilişkin isteklerini karşılamaya çalışmaktadır (Al-Homoud ve diğerleri, 2009, 43).

Kriese ve Scholz $(2012,288)$ ise inşaat sektöründe faaliyet gösterenler ile yatırımcıların, yaşam tarzlarının çerçevelenmesine ve inşasına önemli bir katkıda bulunduklarını belirtmektedirler. Araştırmacılar 1870 ile 2007 yılları arasında İsviçre'nin Basel şehrindeki konut reklamlarını toplumsal ve kültürel değişim bağlamında inceledikleri çalışmalarında genellikle fiziksel ve sosyo-ekonomik özellikler ile tanımlanan sınıf temelli bir toplumdan; giderek daha çok sembolik ve kültürel kodlarla ayırt edilen yaşam tarzlarına gönderme yapan bir toplumsal yapıya geçiş olduğunun altını çizmektedirler. Söz konusu toplumsal yapının reklamlarda da yansıtılması reklam ile kültür arasındaki karşılıklılığa dayanan ilişkinin altını çizmektedir. 
Reklamın, toplumun bir aynası olarak hareket etmesinden kaynaklı toplumun değerlerini, normlarını ve tercihlerini de yansıttığını, dolayısıyla reklamcılıkta peyzaj değerlerini temsil eden işaret ve sembollerin yaygın kullanımının kamuoyunun tercihlerini de ifade ettiğini belirten Maruani ve Amit-Cohen $(2013,92)$ çeşitli inşaat projesi reklamlarını göstergebilimsel açıdan inceledikleri araștırmalarında proje adlarından hareketle reklamlarda "prestij, peyzaj, miras ve proje sahibinin güvenilirliği" olmak üzere dört ana tema olduğu sonucuna ulaşmışlardır. Bu noktada kültürün belirleyiciliğinden hareketle Lawson'da $(2013,8)$ Çin'deki gayrimenkul tanıtım içeriklerinin Avustralya, Avrupa ve Kuzey Amerika'daki içeriklerden farklılık gösterdiğini belirtmektedir

Değinilen çalışmalardan hareketle yapı reklamlarının, fiziksel ihtiyaçların yanı sıra psiko-sosyal ihtiyaçlara da yöneldiği ve bu bağlamda bireysel ve toplumsal kimlikleri ifade edici bir anlatı üzerine inşa edildiği, statü ve prestij sunumunu içerdiği, kültürel yapıyı da barındırarak ikna edici bir iletişim pratiğiyle okuyucuya / izleyici ve dinleyiciye yöneldiği söylenebilir.

\section{Yöntem}

Yapı kavramı, barınma amacını içerdiğinden bu çalışmada konut reklamları analiz birimi olarak seçilmiştir. TV kanallarının prime time aralığında ilk kuşakta gösterilen yapı reklamları araştırmanın örneklemini oluşturmaktadır. Nitel araştırma yaklaşımından hareketle yapılandırılan bu araştırmada (tesadüfi) örneklem kapsamındaki beş reklam "yorumlayıcı içerik analizi” yöntemiyle incelenmiştir.

İçerik analizi, metin içeriği toplama ve analiz etme tekniği olup; içerik, sözcükler, anlamlar, resimler, semboller, düşünceler, temalar ya da herhangi bir iletiye gönderme yaparken; metin ise bir iletişim ortamı görevi gören her türlü yazılı, görsel ya da sözlü öge anlamına gelmektedir (Neuman, 2016, 466). Drisko ve Maschi $(2016,1)$ içerik analizini üç yaklaşım üzerinden ele almakta ve bu yaklaşımları "temel içerik analizi", "yorumlayıcı içerik analizi" ve "nitel içerik analizi" olarak sınıflandırmaktadır. Smith ve Taffler'da $(2000,627)$ içerik analizine yönelik iki alternatif yaklaşımdan bahsetmekte ve bunlardan ilkinin kelimelerin rutin sayımını içeren "biçim yönelimli (nesnel)"; diğerinin ise incelenen metinlerin altında yer alan temalara odaklanan "anlam yönelimli (öznel)" içerik analizi olduğunu dile getirmektedir.

İçeriğin özellikle karmaşık ve farklı yorumlamalara eğilimli olduğu durumlarda yorumlayıcı içerik analizinde kodlama öznel bir süreç olabilmekte (Shimoda, 2010, 171); yorumlayıcı yaklaşım, bağlamdaki anlamı görmenin önemini vurgulamaktadır (Rubin ve Rubin, 1995, 31). Anlam vurgusundan hareketle Krippendorf'da (1980'den akt. Baxter, 1991, 240) içerik analizinin kendisini mesajların yüzeye çıkan özellikleriyle sınırlamaması bunun yerine içeriğin anlamını yorumlaması gerektiğini belirtmektedir.

Metinde, kavramlar arasındaki ilişkileri incelemeyi mümkün kılan yorumlayıcı içerik analizi yöntemi (Dahlen ve diğerleri, 2011, 167) reklam araştırmalarında da kullanılan nitel yöntemsel yaklaşımlardan biridir (Ford ve diğerleri, 1998; Lin, 2008; Lin ve Yeh, 2009). Bu doğrultuda araștırma kapsamındaki beş reklam, Puto ve Wells'in mesaj stratejileri; Aristo, Packard ve Cialdini'nin iknaya ve Maslow'un ise ihtiyaçlara yönelik yaklaşımları temel alınarak incelenmeye; reklamın kültür ve toplum ile olan ilişkisinden hareketle yorumlanmaya çalışılmıştır. 


\section{Bulgular}

Çalıșma, yapı reklamlarını Puto ve Wells'in mesaj stratejileri; Aristo, Packard ve Cialdini'nin iknaya ve Maslow'un ise ihtiyaçlara yönelik yaklaşımlarını temel alarak analiz etmeyi amaçlamaktadır. Bu kapsamda, 2016/2017 yıllarında yürütülen ve kanalların prime time kuşağında yayınlanan beş reklam kampanyasının içeriği yorumlayıcı içerik analizi ve kelime bulutu yöntemleriyle incelenmiștir. Tesadüfi örneklem ile seçilen reklam kampanyaları, içeriği; söylem ve vurgu noktaları temelinde irdelenerek öne çlkan temalar, sözcükler ve metaforlar belirlenmeye çalışılmıştır. Bu bağlamda "Büyükyalı İstanbul", "Yooİstanbul", "Sea Pearl Ataköy", "Skyland İstanbul" ve "Yedi Mavi" reklam kampanyaları literatür bölümünde ifade edilen ikna teorileri ve reklam iletişimi temelinde analiz edilerek yorumlanmıştır.

\section{1. "Büyükyalı İstanbul” Reklam Kampanyası}

Kullanılan Temalar, Çekicilikler ve Vurgu Noktaları: Evlilik / Teklif ve Mücevher Teması, İrrasyonel Çekicilik, Emlak Konut Referansı, Büyük Fırsat ve Vade / Kredi Vurgusu, Alternatifleri Gezin Vurgusu, A(+) Yaşam Görselleri.

Sözcük Havuzu: İyi Yaşam, Masmavi, Gemi, Martı, İstanbul Silüeti, Mahalle, Güven, Tekneler, Deniz, Canlı, Ulaşım, Gelecek, Değerli Mücevher, Prestij, Başarılı Yatırım, Zamansız Tasarım, Seçkin, Detay, Güzellik, Akıl, Büyüleyici, Ayrıcalıklı, Teknoloji.

"İyi yaşam” ön sözü ve kuş sesleriyle açılan Büyükyalı İstanbul reklam filmi, İstanbul şematik algısını inşa eden martı, gemi, deniz ve balıkçı teknesi gibi görseller ve ifadelerle iletişim sürecini başlatmaktadır. "Hayal et" sözüyle sanal olarak inşa edilen ideal yaşam imgesine evrilen reklam, mutlu ve korunaklı aile yaşamına dair vaatlerde bulunmaktadır. Animasyon şeklinde görselleştirilen söz konusu tablo, "badem ezmecisi bile var!” ünlemiyle hedef kitle içgörüsündeki detaya ve lükse seslenebilmektedir. Alışveriș, sofra, yaş günü gibi mutluluk şablonu çizen sahnelerle devam eden reklam, "iyi yaşam" temasını evlilik teklifi ile bütünleștirmektedir (Şekil 1). Yaratıcı strateji açısından duygusal çekicilik dilini kullanan film, "ethos" değerine verdiği önemi "ulaşım kolaylığı" vurgusuyla tamamlamaktadır. İstanbul'un geleceğinin şekillendiği yer vaadiyle sona eren reklamda "Emlak Konut" güvencesi kitlesel ikna açısından Cialdini'nin ifade ettiği "otorite değeri" ve "toplumsal kanıt / sosyal geçerlilik" taktiklerini hatırlatmaktadır. Reklamda kullanılan evlilik teması verdiği aşinalık hissiyle evi "sevgi nesnesi"ne dönüştürebilmektedir. Üçgen Aşk Kuramı'nın belirttiği șekilde tutku / bağlılık / mahremiyet değișkenlerini aile bağı ve güven söylemiyle tesis eden reklam, evlilik teklifine verdiği "evet!" yanıtı ile anlatı yönünü güçlendirmektedir (Şekil 2). Öte yandan reklamda yer alan "mahalle”, "balıkçı tekneleri", "martı" gibi uyaranlar ikna açısından Packard'ın "değer teminatı"na atıf içermekte ve sosyal algıya uygun iletişimler içermektedir.
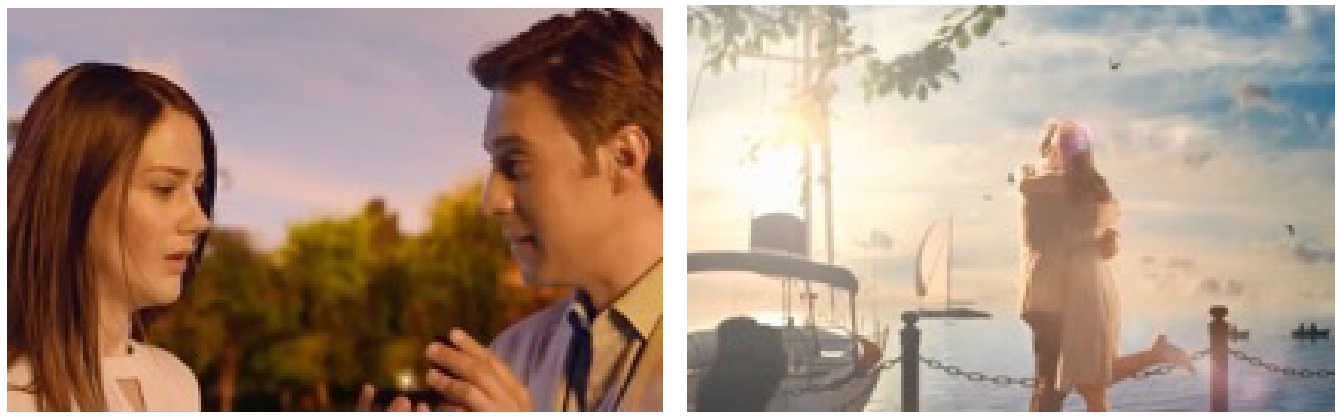

Şekil 1 ve 2: "Büyükyalı İstanbul" Reklam Filminden Kareler 
Projenin diğer reklamlarında kullanılan mücevher (Şekil 3), taşlı ve parlak proje logosunu ve statü anlamıyla "ev"i ön plana çıkarmaktadır. Packard'ın gizli ihtiyaçlarından "ego tatmini"ne seslenen bu anlam, evin prestijini ev sahibine aşılamayı amaçlamaktadır. Sıcak aile kurma hikayesinden; evlilik teklifinden statü ve prestij sahibi ev sahiplerine dönüșen reklam dili, sunduğu "fırsat" son sözüyle rasyonel çekicilik stratejisini uygulamaya dökmektedir. Verdiği bilgilerle (vade, kredi, faiz oranları) Aristo'nun ifade ettiği "logos” değerini artıran reklam filmi, İhtiyaçlar Hiyerarşisi'nde yer alan saygınlık basamağını anımsatmaktadır. Öte yandan "sınırlı süre" için geçerli kampanya diliyle Cialdini'nin "azlık prensibi" ilkesini yürürlüğe sokan reklam packshot'ı, sunduğu referanslarla (Toki, Emlak Konut) tüketicinin güven duygusuna seslenmektedir. Konut gibi yüksek ilginlik içeren ürün reklamına yedirilen imza sahnesi de reklam filminin “logos”; yani kanıtgücünü artırabilmektedir.

Kampanyanın bir diğer reklam filminde (Şekil 4) ise transformasyonel dil daha da pekiştirilerek lüks nesneler (mücevher, antika otomobil, tekne) üzerinden elit yaşam tarzı somutlaştırılmaktadır. "Zamansız tasarım"ın "prestij" ile buluştuğu reklam söyleminde erkek ve kadın seçkin detaylarda bir araya gelmektedir.Verilen pozlarla inşa edilen gösterişli psikografi, nesneler; gösterenler üzerinden kimlikler yaratmaktadır. Gizli ihtiyaçlardan biri olan "güç" duygusuna ve statü temelli benlik algısına hizmet eden söz konusu "kimlikler", İstanbul manzarasını arka plan haline getirmektedir.
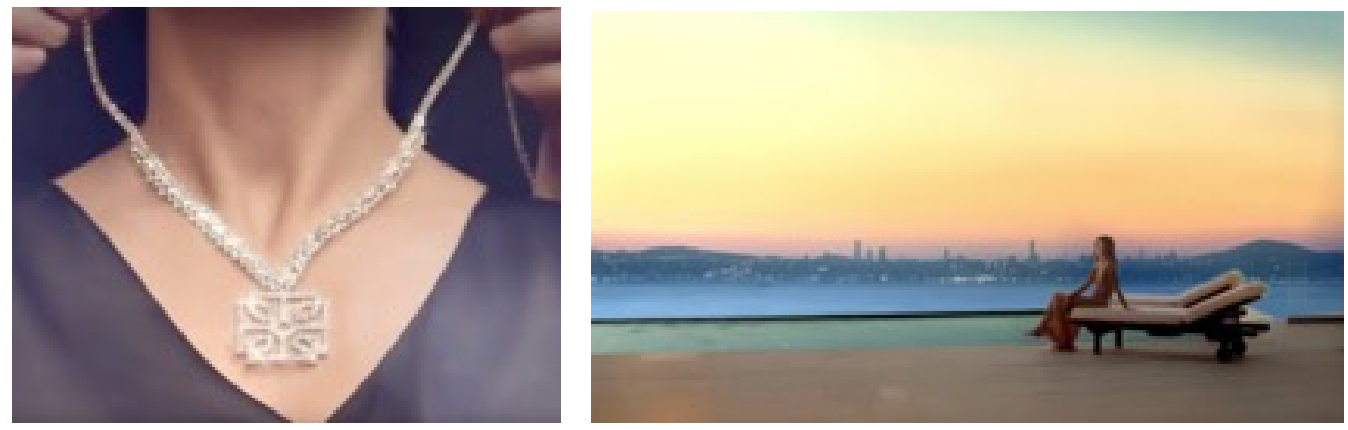

Şekil 3 ve 4: "Büyükyalı İstanbul" Reklam Kampanyasından Kareler

\section{2. "Yoolstanbul" Reklam Kampanyası}

Kullanılan Temalar, Çekicilikler ve Vurgu Noktaları: Satranç Metaforu, Golf ve Dans Teması, Ünlü Çekiciliği, A(+) Yaşam Görselleri.

Sözcük Havuzu: Dünya Standartları, Zor Beğenen, Tarz, Farklılık, Tutku, Zevk, Akıl, İhtiras, Boğaz Manzarası, Gurur.

Dünya standartlarına atıfla başlayan Yooİstanbul reklam filmi, ünlü; star çekiciliğini kullanarak referans değerini kuvvetlendirmekte; "deri koltuk", "dünya küresi” ve "ayna” nesneleriyle vermek istediği mesajı metalaştırmaktadır. Selçuk Yöntem'in aynaya bakarak papyonunu düzelttiği kare sonrasında kampanya; zor beğenen, tarz sahibi, golf oynayan birey üzerinden "artistik" kanıtlarını dizayn etmektedir. Karizmatik ses tonu ve renk paleti eşliğinde dans sahnesine taşınan anlam zevk, akıl, satranç, mücevher, ihtiras ve gurur vurgusuyla mesajlarını ifad eye dönüştürmektedir (Şekil 5 ve 6). Selçuk Yöntem'i ideal ben haline getiren reklam filmi, siyah tonları, güzel kadın imgesi, mücevher takma ritüeli beraberinde imaj odaklı bir reklam iletişimi içermektedir. Duygusal satış vaadini (ESP) kullanan kampanya reklamı Puto ve Wells'in ifade ettiği "imaj" temelli transformasyonel dili hayata geçirmektedir. Kullanıcı imajından hareketle "ego tatmini" tasarlayan reklam yaratıcı stratejisi, 
"kendini gerçekleştirme" savını ünlü isim ve sunmaya çalıștığı yaşam tarzı paralelinde uygulamaya çalışmaktadır. Pembe dizi atmosferinde akan ve imaj tesirinde geçen 40 saniye sonrasında packshot ekranında "Starck" kanıtını dillendiren reklam filmi, Cialdini'nin belirttiği gibi ikna sürecini "otorite" dayanağıyla şekillendirmektedir.
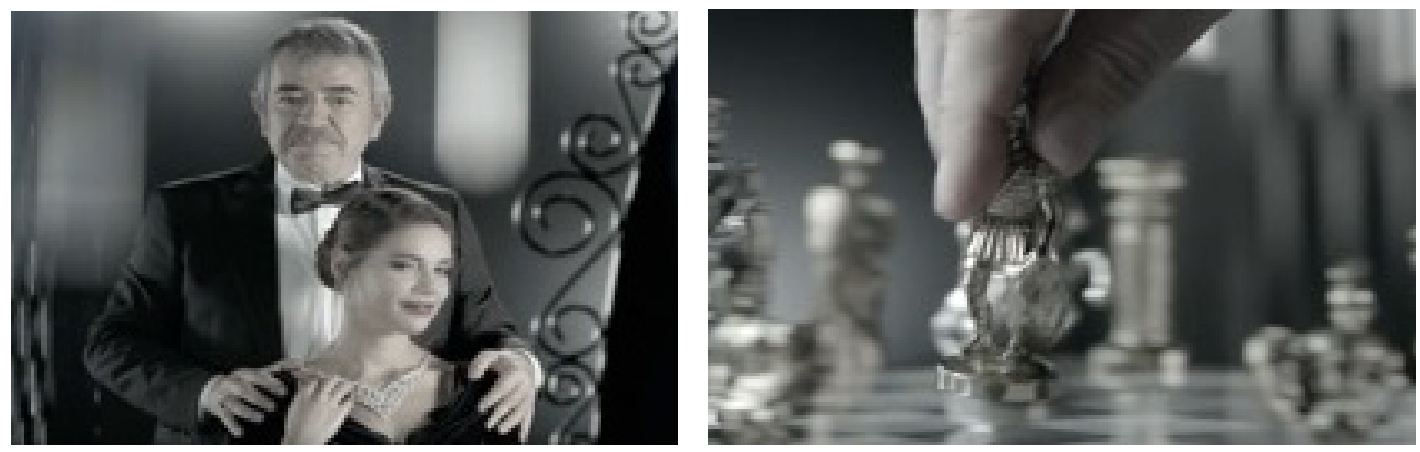

Şekil 5 ve 6: "YooIstanbul" Reklam Filminden Kareler

\section{3. "Sea Pearl Ataköy" Reklam Kampanyası}

Kullanılan Temalar, Çekicilikler ve Vurgu Noktaları: Elmas Teması, İrrasyonel Çekicilik, Kuzu Grup Referansı ve A(+) Yaşam Görselleri.

Sözcük Havuzu: Deniz Manzarası, Sahil, Botanik Park, Lüks, Deniz, Ulaşım, İhtişam, Getiri.

Deniz üzerinde parçalanan ve birleșen elmasların "1" yazdı̆̆ı, Rihanna'nın "Diamonds (Elmaslar)" şarkısı fonunda, "deniz manzarası", "barok peyzaj alanı", "sahil şeridi", "lüks otel ayrıcalıkları", "denizden ulaşım avantajı" ve "getiri değeri” iddialarını dillendiren Sea Pearl Ataköy reklam filmi ışıltılı görselliğiyle dikkat çekmektedir (Şekil 7). Packard'ın ifade ettiği "güç duygusu” na seslenen reklam irrasyonel çekicilik stratejisini kullanarak "ihtişamı yaşayanların yeni adresi" sloganıyla kapanış yapmaktadır (Şekil 8). Animasyon görüntüler birlikteliğinde tekne, yelken ve elmas gibi statü imleci nesneler içeren kampanya, "getiri değeri" savını Forbes Türkiye referansı ile sunmaktadır. Cialdini'nin söylediği "otorite" ve "sosyal geçerlilik" ikna kısayollarını / taktiklerini devreye sokan söz konusu dil, projenin fiziksel ve sosyal boyutunu yüzeye taşımaktadır. Konutun konumu ve avantajları eşliğinde sosyal statüye etkisine atıf içeren söz konusu iki boyut -alanyazında aktarılan- Ramer-Biel ve First (2011) tarafından yapılan araștırmayı anımsatmaktadır. Öte yandan Sea Pearl Ataköy reklam kampanyasında Collins ve Kearns'in (2008) ifade ettiği konutun "sembolik" işlevi belirgin bir şekilde görülmekte; bu sayede hedef kitle nezdinde İhtiyaçlar Hiyerarşisi'nin dördüncü ve beşinci basamaklarına ulaşılmaktadır.
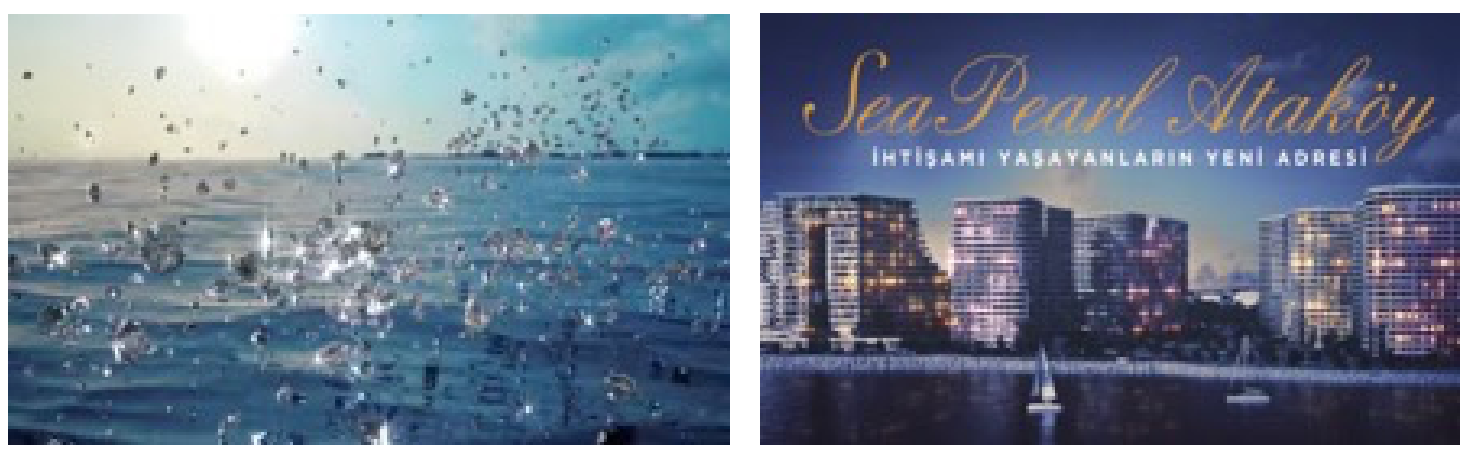

Şekil 7 ve 8: "Sea Pearl Ataköy" Reklam Kampanyasindan Kareler 


\section{4. "Skyland İstanbul" Reklam Kampanyası}

Kullanılan Temalar, Çekicilikler ve Vurgu Noktaları: Sohbet / Kafe ve İstanbul Tarihi Teması, Siyah Orkide Metaforu, İrrasyonel Çekicilik, Lansman Fiyatı Vurgusu ve $\mathrm{A}(+)$ Yaşam Görselleri.

Sözcük Havuzu: Hayaller, Yüksek, Havall, Rezidans, Son Gözde, Merkez, Lokasyon, Benzersiz.

Kafe mekanı eşliğinde sohbet mizansenini kullanan Skyland İstanbul, gökyüzüne doğru yükselen hayaller savını "siyah orkide" nesnesiyle bütünleştirmektedir (Şekil 9 ve 10). İknada kullanılan "azlık prensibi"ne gönderme imkanı sunan meta, az olanın değerli olduğu yönündeki içgörüyü desteklemektedir. Duygusal satış vaadi temelinde şekillenen reklam yaratıcı stratejisi, yükselen hayallerin Skyland İstanbul'a kadar çıkacağı söylemini "inci kolye", "iphone", "siyah orkide", "piyano (ve melodisi)" gibi uyaranlarla imaj odaklı biçimde dile getirmektedir. İrrasyonel yönünü "ödemeleri de çok iyi” gibi göreceli bir ifadeyle besleyen reklam filmi, net bilgiler sunmayarak Puto ve Wells'in betimlediği transformasyonel iletişim anlayışını benimsemektedir. Bunun yanı sıra kampanya, yaşam tarzı çerçevelemesinde Kriese'nin ve Scholz'un (2012) belirttiği gibi sembolik ve kültürel kodlarla ayırt edilen göndermeler içermektedir. Başlangıçta "çocuk konusu mu hala?" satırı ile tanıdıklık hissi yaratan ve aile değerlerine saygı duruşunda bulunan reklam metni, Packard'ın "değer teminatı" ilkesine uygun davranmaktadır. Son karede sunulan "Eroğlu" ve "lansman fiyatlarıyla" ifadesi 35 saniyelik reklam filmini -Maruani ve Amit-Cohen'in (2013) dillendirdiği gibi- "prestij" ve "proje sahibinin güvenilirliği” temaları üzerinden sonlandırmaktadır.
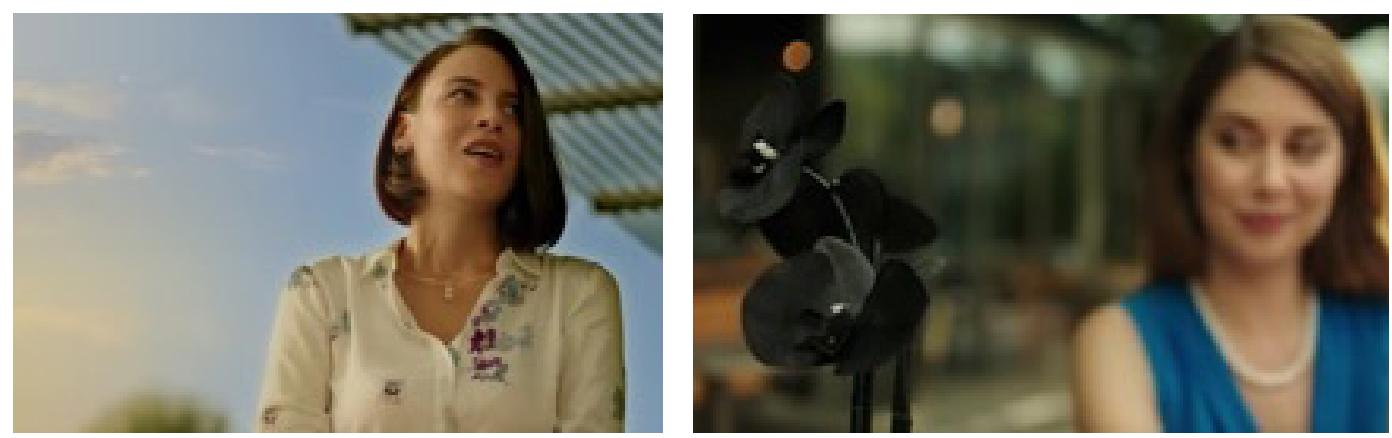

Şekil 9 ve 10: "Skyland İstanbul" Reklam Filminden Kareler

Kampanyanın diğer reklam filminde ise "Kız Kulesi M.Ö. 341", "Beyazıt Kulesi 1749 " ve "Galata Kulesi 507" görselleriyle Skyland İstanbul yapısı eșleştirilmekte ve Packard'ın belirttiği "köken" gizli ihtiyacı harekete geçirilmektedir (Şekil 11). İstanbul'u İstanbul yapan "benzersiz güzellikler"den biri olacağı vaadiyle sunulan proje, binalar üzerine yansitılan Kız, Galata ve Beyazıt Kuleleri ile söz konusu iddiasını görselleştirmektedir (Şekil 12). "İş yaşamı", "lokasyon", "sunulan imkanlar" gibi vurgularla "high society (yüksek sosyete)" algısı oluşturan reklam iletişimi "İstanbul kadar benzersiz" sloganıyla kent değerini / değerlerini teminat altına almaktadır. Söz konusu teminat ile hedef kitlenin -Packard'ın nitelediği"ölümsüzlük" gizli ihtiyacına ve -Cialdini'nin açılladığı- "sosyal geçerlilik" ve "beğenme" eğilimlerine seslenilmektedir. 

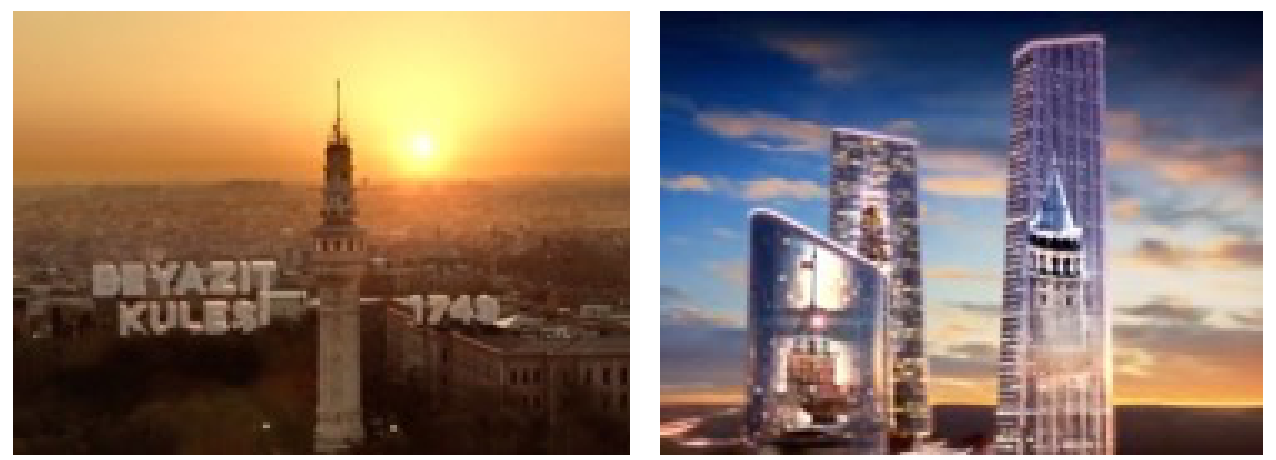

Şekil 11 ve 12: "Skyland İstanbul" Reklam Kampanyasından Sahneler

\section{5. "Yedi Mavi" Reklam Kampanyası}

Kullanılan Temalar, Çekicilikler ve Vurgu Noktaları: Aile Teması, İrrasyonel Çekicilik, A(+) Yaşam Görselleri, Cazip Fiyat ve Örnek Daire Vurgusu.

Sözcük Havuzu: Asalet, Lüks, Işıltı, Göz Alıcl, Detay, İhtişam, Sonsuzluk, Gökyüzü, Mutluluk, Farklılık, Cadde, Mağaza, Prestij, Ayrıcalık, Cazip, Ufuk, Hayaller, Gözde, Rüyalar, Muhteşem, İlham, Deniz.

Siyah beyaz renk paletiyle mavi rengini baskın hale getiren Yedi Mavi reklam filmi, asalet, lüks, ışıltı, göz alıcı detaylar, ihtişam, sonsuz gökyüzü, mutluluk gibi anahtar sözcüklerle "prestijli yaşam" algısını inşa etmektedir. Kurumsal algı bileșenlerinden biri olan algıları imaj temelinde görünür hale getirmeye çalışan kampanya, lüks araba, mücevher, tekne ve gösterişli dekoratif ögeler / semboller üzerinden psikografi üretmektedir. Çekirdek aile hayatını mavi donanımlı göstergeler ve söylemler çerçevesinde kurgulayan reklamda "prestijli hayat", yaratılan mizansenlerle görünür kılınmaktadır (Şekil 13 ve 14). Yaratıcı strateji olarak ESP ve kullanıcı yönlü imaj stratejisini benimseyen kampanya dili, "örnek daire" davetiyle Larson'un "borçlu hissettirme" ve Cialdini'nin "karşılıkta bulunma" ikna taktiklerini pratiğe dökmektedir. Referans değeri şeklinde packshot ekranında sunulan TOBB, Kalkavanyapı gibi otoriteler ile 47 saniye süren iletinin biliş; logos boyutu öne çıkarılmaktadır.
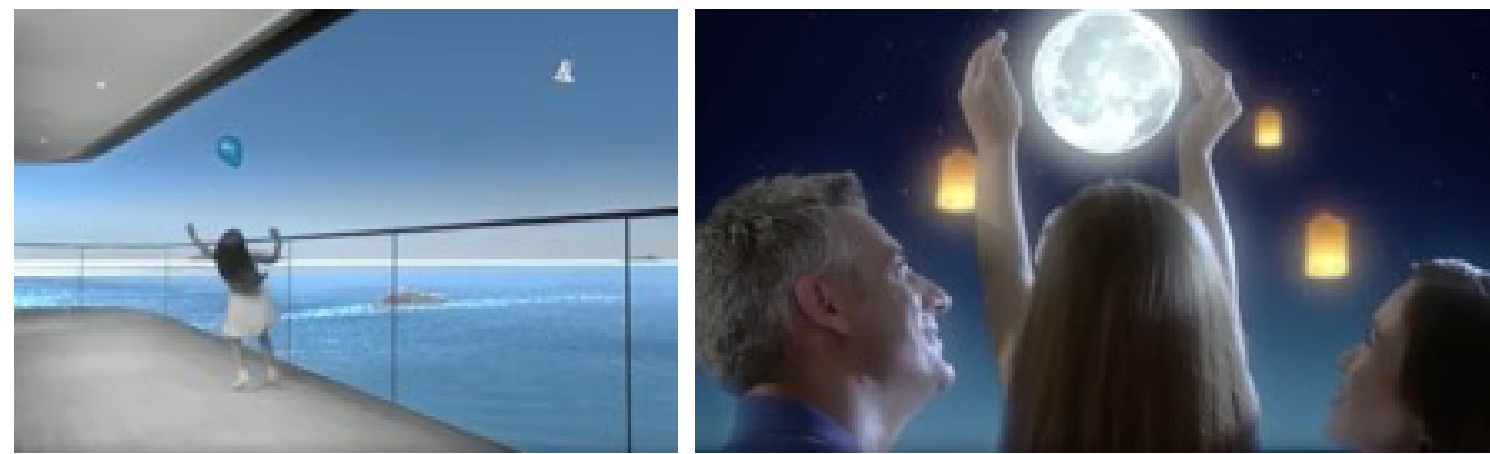

Şekil 13 ve 14: "Yedi Mavi" Reklam Filminden Kareler

Yedi Mavi reklamlarının diğerinde ise "aile" göstereninin yerini bireysel formattaki ve çift formatındaki sunumlar almaktadır. "Gökdelenler", "saksafon", "rüyalar", "tekne”, "alışveriș", "havuz" gibi sembolik iletişim unsurlarıyla bezenen reklam filminde, proje için üretilen jenerik ön plana çıkarılarak "şehrin yeni gözdesi", "hayaller" ve "rüyalar" sözleri vurgulanmaktadır (Şekil 15 ve 16). Gerçek ve animasyon görüntüleri bir arada kullanan reklam filmi, yumuşak geçişleri ve düş desenlemesi formatındaki 
akışını "pathos (duygu)" temelinde kurgulamaktadır. Retoriksel çekicilik yanında hedef kitlenin gizli ihtiyaçlarından biri olan "ego tatmini"ne seslenen "etiket"ler içeren kampanya, Americus ve diğerlerinin (2009) işaret ettiği gibi söz konusu etiketler aracılığıyla statüler; kimlikler oluşturabilmektedir. Ayrıca Maruani ve AmitCohen (2013) tarafından betimlenen "prestij" ve "peyzaj" temalarının yoğun bir şekilde kullanıldığı gözlemlenmekte; rasyonel gerekçe ve logos (fiyat, vade, teknik bilgi) faktörlerinin yerini transformasyonel dil almaktadır. SES (Sosyo Ekonomik Statü) grupları açısından $\mathrm{A}(+)$ ve B segmentine seslenen ve doğal yaşama öykünme içeren kampanya, gülen; mutlu insanları ile "muhteșem yaşam" savını satış vaadine yedirmektedir. Bu bağlamda ikna süreci olarak "ego" ve "güç" ihtiyaçlarına seslenen reklam anlatısı, Mittal'in (2015) ileri sürdüğü tüketici benliği ile markaların sembolik imgeleri arasındaki "eşleștirme" görevini yerine getirebilmektedir.
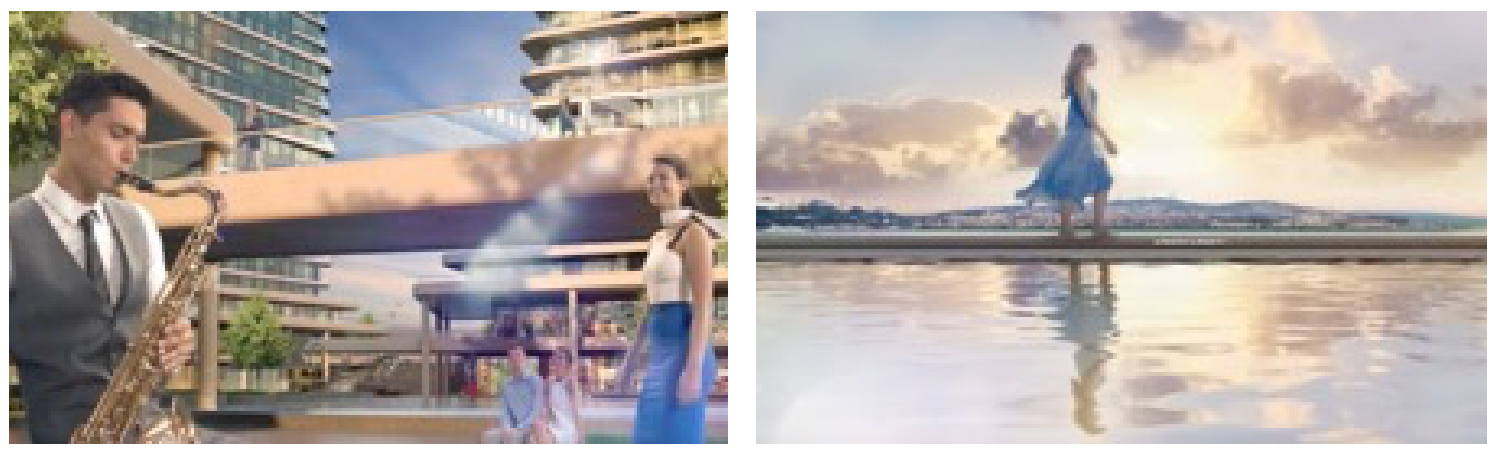

Şekil 15 ve 16: "Yedi Mavi" Reklam Kampanyasindan Sahneler

Söz konusu yapı reklamları kelime bazlı incelendiğinde en çok rastlanan ifadelerin imaj kökenli olduğu gözlemlenmektedir. Bu doğrultuda Şekil 17'de görselleştirilen kelime bulutu, incelenen beş reklam kampanyasında sıklıkla kullanılan ifadelerden oluşmaktadır. Her biri İstanbul projesi olan yapı reklamlarında "prestij", "ihtişam", "manzara", "ayrıcalık", "rüya”, "hayal”, "ulaşım”, "lüks" sözcükleri en çok rastlanan ifadeler olarak dikkat çekmekte ve tercih edilen transformasyonel dil yüzeye çıkmaktadır. İncelenen yapı reklamlarında Puto ve Wells'in irrasyonel çekicilik şeklinde kategorize ettiği mesaj stratejileri kullanılmakta, "soyut" kavramlar, "statü" gösterenleri ve "sembolik" tüketim çağrışımları ana retoriği temsil etmektedir.

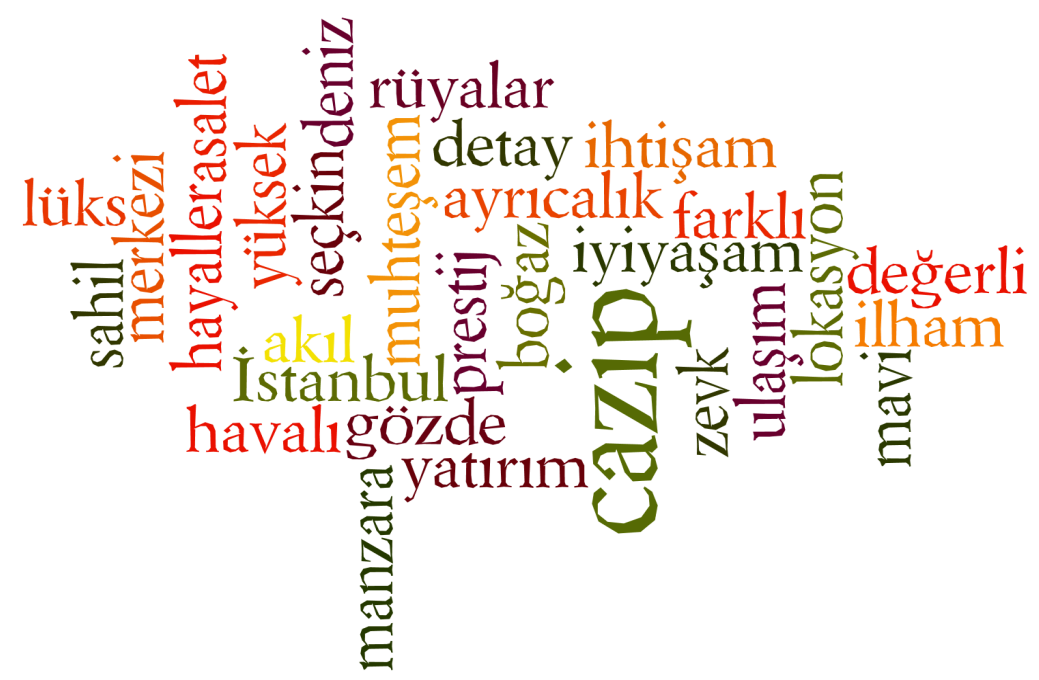

Şekil 17: Konut Reklamlarının "Kelime Bulutu" 


\section{Sonuç ve Tartışma}

Analiz edilen reklam kampanyalarında "transformasyonel retorik" temelinde "irrasyonel çekicilik" türünün baskın bir şekilde tercih edildiği görülmektedir. Kampanyalarda Packard'ın belirttiği "ego tatmini”, "değer teminatı", "güç duygusu" ve "köken arayışı" ile Cialdini'nin dillendirdiği "sosyal geçerlilik / toplumsal kanıt", "beğeni değeri" ve "azlık prensibi" taktiklerine uygun iletişimler tasarlandığı gözlemlenmektedir. Bu durum soyut kavramlar, semboller ve sosyal algı paralelinde seyreden imaj yönelimli reklam dilini ortaya çıkarmaktadır. Kullanıcı ve marka imajına odaklanan ve bu sebeple "logos; bilgi" yerine "pathos; duygu" değerini tercih eden yapı reklamları, duygusal satış vaadini (ESP) temel mesaj stratejine dönüştürmektedir. Artistik kanıtlarını -objektif bir tanımından ziyade- $\mathrm{A}(+)$ yaşam görselleri, sembolik tüketim mizansenleri, yaşam tarzı söylemi çerçevesinde subjektif bir formatta inşa eden reklam anlatıları, Maruani ve Amit-Cohen (2013) tarafından tasvir edilen "prestij", "peyzaj", "proje sahibinin güvenilirliği” ana temalarını kullanmaktadır. Ayrıca Mittal'in (2015) işaret ettiği tüketici / marka eşleştirmesi reklamlarda yaratılan profiller ve yașam standartları üzerinden sembolleri, nesneleri ve imajları birer araç haline getirebilmektedir. Maslow'un hiyerarşisinde dördüncü ve beşinci adımlara karşılık gelen SES, statü ve "ideal / rol benlik" kaygılı bu durum, bireyin gizli ihtiyaçlarını harekete geçirmeyi hedeflemektedir. Geleneksel kitle iletişim araçları arasındaki popülerliğini koruyan TV'de son derece niş bir hedef kitleye seslenen reklamların söz konusu gerçeklikten uzak imaj tabanlı iletişim tasarımları tartışmalı görünmektedir.

Öte yandan ortaya çıkan "yapı reklamları kelime bulutu”, incelenen reklam metinlerinde yer alan sıfatların psikografi / imaj temelli yapısını gözler önüne sermektedir. Konutların yüksek ilginlik içeren ürün grubu olmasına karşın kampanyalarda kullanılan söylemin rasyonel ve logos retoriğine sahip olmaması dikkat çekici görünmektedir. Bu durum Kriese ve Scholz (2012) tarafından inşaat sektörünün yaşam tarzı inşa etme rolüne işaret etmekte; söz konusu rolü reklam iletişimcileri de benimsemektedir. Reklamın pazarlama iletişimi yanında sembolik ve kültürel işlevleri de olduğunu belirten Americus ve diğerleri (2009) yapı reklamlarının tüketiciyi farklılaştıran "kimlik" ve "etiket" algısına hizmet ettiğini iddia etmektedir. Söz konusu iddia incelenen yapı reklamları çerçevesinde gerçekçi görünmekte ve Pollay'in (1986) reklama yönelik dile getirdiği “çarpıtılmış ayna" metaforunu hatırlatmaktadır.

\section{Kaynakça}

Ajzen, I. (2005). Attitudes, personality and behavior. England: Open University Press.

Al-Homoud, M., Al-Oun, S., Smadi, A. and Al-Hindawi, A. M. (2009). Exploring sales advertising in the housing market in Jordan. International Journal of Housing Markets and Analysis, 2(1), 39-56.

Ambler, T. (2000). Persuasion, pride and prejudice: How ads work. International Journal of Advertising, 19(3), 299-315.

Americus, R., Cohen, J. B., and Bhattacharjee, A. (2009). When brands are built from within: A social identity path way to likingand evaluation. In Deborah J. MacInnis, C. Whan Park and Joseph R. Priester (Eds.), Handbook of brand relationships (pp. 124-150). Armonk, NY: M. E. Sharpe. 
Anderson, C., John, O. P. and Keltner, D. (2012). The personal sense of power. Journal of personality, 80(2), 313-344.

Baxter L. A. (1991). Content analysis. In B. M. Montgomery and S. Duck (Eds.), Studying interpersonal interaction (pp. 239-254). NY: Guilford Press.

Beasley, R. and Danesi, M. (2002). Persuasive signs: The semiotics of advertising. Berlin: Mouton de Gruyter.

Borchers, T. (2013). Persuasion in the media age. Long Grove, Illinois: Waveland Press.

Burke, P. J. and Stets, J. E. (2009). Identity theory. Oxford University Press.

Chand P. and Chaudhary, S. (2012). Advertising discourse: Studying creation and perception of meaning. International Journal of English and Literature, 3, 40-49.

Cheung, S. C. and Ma, E. K. (2005). Advertising modernity: Home, space and privacy. Visual Anthropology, 18(1), 65-80.

Chryssochoou, X. (2003). Studying identity in social psychology: Some thoughts on the definition of identity and its relation to action. Journal of Language and Politics, 2(2), 225-241.

Cialdini, R. B. (2001). The science of persuasion. Scientific American, 284(2), 76-81.

Collins, D. and Kearns, R. (2008). Uninterrupted views: real-estate advertising and changing perspectives on coastal property in New Zealand. Environment and Planning A, 40(12), 2914-2932.

Cutrona, C. E. and Russell, D. W. (1987). The provisions of social relationships and adaptation to stress. In Jones, W. H., Perlman, D. (Eds.), Advances in personal relationships (Vol. 1, pp. 37-67). Greenwich, CT: JAI Press.

Dahlen, H., Jackson, M., Schmied, V., Tracy, S. and Priddis, H. (2011). Birth centres and the national maternity services review: Response to consumer demand or compromise?. Women and Birth, 24(4), 165-172.

Davies, P. and Cummings, E. (1994). Marital conflict and child adjustment: An emotional security hypothesis. Psychological Bulletin, 116(3), 387-411.

Dittmar, H. (2008). Understanding the impact of consumer culture. In Helga Dittmar (Ed.), Consumer Culture, Identity and well-being: The Search for the 'Good life' and the 'Body perfect' (pp. 1-24). New York: Psychology Press.

Drisko, J. W. and Maschi, T. (2016). Content analysis. Oxford, NY: Oxford University Press.

Elliott, R. And Wattanasuwan, K. (1998). Brands as symbolic resources for the construction of identity. International Journal of Advertising, 17(2), 131-144.

Ford, J. B., Voli, P. K., Honeycutt Jr, E. D. and Casey, S. L. (1998). Gender role portrayals in Japanese advertising: A magazine content analysis. Journal of Advertising, 27(1), 113-124.

Green Jr, S. E. (2004). A rhetorical theory of diffusion. Academy of Management Review, 29(4), 653-669.

Higgins, C. and Walker, R. (2012). Ethos, logos, pathos: Strategies of persuasion in social / environmental reports. Accounting Forum, 36(3), 194-208. 
Horrobin, S. (2006). Immortality, human nature, the value of life and the value of life extension. Bioethics, 20(6), 279-292.

Jhally, S. (1990). The codes of advertising. Fetishism and the political economy of meaning in the consumer society. New York: Routledge.

Kriese, U. and Scholz, R. W. (2012). Lifestyle ideas of house builders and housing investors. Housing, Theory and Society, 29(3), 288-320.

Lawson, G. (2013). A rhetorical study of in-flight real estate advertisements as a potential site of ethical transformation in Chinese cities. Cities, 31, 85-95.

Lee, D. W. (2010). Decoding the persuasion strategies used in the advertising targeted for children. Korean Journal of Communication Studies, 18(4), 31-50.

Lin, C. L. (2008). Sexual issues: The analysis of female role portrayal preferences in Taiwanese print ads. Journal of Business Ethics, 83(3), 409-418.

Lin, C. L. and Yeh, J. T. (2009). Comparing society's awareness of women: Mediaportrayed idealized images and physical attractiveness. Journal of Business Ethics, 90(1), 61.

Maruani, T. and Amit-Cohen, I. (2013). Marketing landscapes: The use of landscape values in advertisements of development projects. Landscape and Urban Planning, 114, 92-101.

Maslow, A. (1954). Motivation and personality. New York: Harper \& Row.

Maslow, A. (2010). Towards a psychology of being. Eastford: Martino Fine Books.

Millan, E. and Reynolds, J. (2014). Self-construals, symbolic and hedonic preferences, and actual purchase behavior. Journal of Retailing and Consumer Services, 21(4), 550-560.

Mittal, B. (2015). Self-concept clarity: Exploring its role in consumer behavior.Journal of Economic Psychology, 46, 98-110.

Moring, I. (2000). Scales of space, place and money. Discursive landscapes of regional inertia, identity and economic change. Nordicom Review, 21(2), 171-189.

Neuman, W. L. (2016). Toplumsal araştırma yöntemleri: Nitel ve nicelik yaklaşımlar (8. Baskı). (Çev. Sedef Özge). Ankara: Yayın Odası Yayınları.

Nicholson, C. Y., Compeau, L. D. and Sethi, R. (2001). The role of interpersonal liking in building trust in long-term channel relationships. Journal of the Academy of Marketing Science, 29(1), 3.

O’Keefe, D. J. (1990). Persuasion. Theory and research, Sage, Newbury Park, CA.

O'Keefe, D. J. (2004). Trends and prospects in persuasion theory and research. In J. S. Seiter \& R. H. Gass (Eds.), Perspective on persuasion, social influence, and compliance gaining (pp. 31-43). Boston, MA: Allyn \& Bacon.

Olson, J. M. and Zanna, M. P. (1993). Attitudes and attitude change. Annual Review of Psychology, 44(1), 117-154.

O'Shaughnessy, J. and O'Shaughnessy, N. J. (2004). Persuasion in advertising. London: Routledge. 
Packard, V. (1964). The hidden persuaders. New York: Pocket.

Page, J. and Thelwell, R. (2013). The value of social validation in single-case methods in sport and exercise psychology. Journal of Applied Sport Psychology, 25(1), 61-71.

Pollay, R.W.(1986). The distorted mirror: reflections on the unintended consequences of advertising. Journal of Marketing, 50(2), 18-36.

Puto, C. P. and Wells, W. D. (1984). Informational and transformational advertising: The differential effects of time. Advances in Consumer Research, 11, 638-643.

Ramer-Biel, S. and First, A. (2011). No home away from home: The discourse of home in ads for third-age housing. Popular Communication, 9(3), 181-195.

Rocha, E. (2013). The woman in pieces: Advertising and the construction of feminine identity. SAGE Open, October-December: 1-12.

Rubin, H. J. and Rubin, I. S. (1995). Qualitative interviewing: The art of hearing data. Thousand Oaks, CA: Sage Publications.

Schembri, S., Merrilees, B. and Kristiansen, S. (2010). Brand consumption and narrative of the self. Psychology \& Marketing, 27(6), 623-637.

Shimoda, T. (2010). Media portrayals of motherhood in parenting magazines in contemporary Japan. In M. Porter and J. Kelso (Eds.), Mother texts: Narratives and counter narratives (pp. 163-178). Newcastle, UK: Cambridge Scholars Publishing.

Smith, M. and Taffler, R. J. (2000). The chairman's statement-A content analysis of discretionary narrative disclosures. Accounting, Auditing \& Accountability Journal, 13(5), 624-647.

Stavrakakis, Y. (2000). On the critique of advertising discourse: A Lacanian view. Third Text, 14(51), 85-90.

Steinberg, S. (2006). Persuasive communication skills: Public speaking. Cape Town: Juta.

Sternberg, R. J. and Lubart, T. I. (1999). The concept of creativity: Prospects and paradigms. In R. J. Sternberg (Ed.), Creativity research handbook (pp. 3-15). New York: Cambridge University Press.

Thoits, P.A.(1983). Multipleidentities and psychological well-being: Areformulation and test of the social isolation hypothesis. American Sociological Review, 174-187.

Tiwsakul, R. A. and Hackley, C. (2012). Postmodern paradoxes in Thai-Asian consumer identity. Journal of Business Research, 65(4), 490-496.

Verlegh, P. W. J., Fransen, M. L. and Kirmani, A. (2015). Persuasion in advertising: When does it work, and when does it not?. International Journal of Advertising, 34(1), 3-5.

Wharton, C. (2015). Advertising: Critical approaches. Abingdon, Oxon: Routledge.

APA Dictionary of Psychology. (t.y.). Erişim: 06 Ekim 2017, https://dictionary.apa. org/love 
APA Dictionary of Psychology. (t.y.). Erişim: 10 Ekim 2017, https://dictionary.apa. org/reciprocity

English Oxford Living Dictionaries. (t.y.). Erişim: 10 Ekim 2017, https:// en.oxforddictionaries.com/definition/consistency

Merriam-Webster. (t.y.). Erişim: 10 Ekim 2017, https://www.merriam-webster. com/dictionary/authority

Türk Dil Kurumu Güncel Türkçe Sözlük. (t.y.). Erişim: 13 Ekim 2017, http:// www.tdk.gov.tr/index.php? option=com_gts\&arama=gts\&guid=TDK. GTS.5ad4f3f262f0d4.80338980 
